\title{
WHAT IS THE FINANCIAL LITERACY LEVEL OF ECUADORIAN POLYTECHNIC UNIVERSITY STUDENTS? AN ATTEMPT TO EVALUATE THEIR PERFORMANCE
}

\author{
S.M. Méndez Prado ${ }^{1,2}$, P. Everaert ${ }^{2}$, M. Valcke ${ }^{3}$ \\ ${ }^{1}$ Escuela Superior Politécnica del Litoral ESPOL (ECUADOR) \\ ${ }^{2,3}$ Ghent University (BELGIUM)
}

\begin{abstract}
University students were evaluated about financial literacy (FL) with a customized survey based on the contributions of many research studies including the OECD toolkit. Demographic and socioeconomic variables were related to three dimensions of FL, financial knowledge (FK), financial behavior (FB) and financial attitude (FA) as the content of this survey. Students with better financial background reached better FL scores and students without this background, but strong numeracy formation obtained the maximum Fk score as well. The FL valuation index is proposed as the simple average of the addition points in every dimension listed. This document pretends to share the principal findings to extend the discussion and enhance the results, to be used by policymakers as an essential contribution to the FL subject in Ecuador.
\end{abstract}

Keywords: Financial literacy, financial attitude, financial knowledge, financial behavior, university students, Confirmatory factor analysis, multivariate analysis, KFD, OECD.

\section{INTRODUCTION}

The lack of financial literacy and education is one of the principal reasons attributed to financial crises across the world during the last decade (1). For that reason, during 2003 the Organization for Economic Cooperation and Development (OECD) a world level, Andean Development Corporation (CAF) a regional level, and Superintendence of Banks (SBS) in Ecuador since 2013 asked to Financial Institutions offer to their clients, financial education programs to tackle this problem at the national level, in the last case (2). In this way, several efforts around the world had happened to address this issue affecting the financial stability of a country. The OECD is leading all the movement and rules to promote FL.

Analyze the financial behavior of university students, is the best way (3) to have an idea and to dimension the scope about the financial literacy level of a country's youth and the most educated population as well.

The original motivation to begin this research is to know how well prepared the students are when they take some key financial decisions (KFD) in their life. For this purpose, KFD was defined as relevant long-lasting goods such as house, car, and pension plan (4-6).

The research question in this stage is how much financially literate the ESPOL polytechnic students are, and we have tried to know their priority or preference about the key financial decisions (KFD) and an extra objective is to propose the construction of a financial literacy indicator with the data obtained in this research.

One of the references building an adapted financial literacy evaluation instrument for Ecuador, in this study is Potrich et al. (7) following their three constructs, financial attitude (FA), financial behavior (FB), and financial knowledge (FK) suggested too by OECD. Conceptually, Financial knowledge is acquired lifelong education, Financial Behavior is the action of how people are facing the decision- 
making process, and financial attitude is more focused on the individuals' idiosyncratic background (8).

The index proposed helps to calculate the financial literacy score using the data from a multiple choices survey from a sample of 478 university students of ESPOL. The index will be useful to evaluate any university student who takes this survey giving their respective FL score.

The document is presented as follows: 1) Introduction, 2) Methodology, 3) Results, 4) Conclusions.

\section{METHODOLOGY}

The FL survey includes of 61 questions divided into five sections: $A=$ demographic (16), $\mathrm{B}=$ financial place and time with "informative answer" (1); $\mathrm{C}=$ Financial Attitude (18), $\mathrm{D}=$ Financial Behavior "validate answer" (13) and, $\mathrm{E}=$ Financial knowledge with "correct answer" (13). $43 \%$ of those questions were prepared or adapted by the authors and complemented from different studies published in the literature (7-11). An special question is included, the participants are asked to choose their priority to invest among retirement account, house and car as the three Key Financial Decisions (KFD).

The sample was divided into three categories, using their financial background as a criterion: natural, enlightened and unfamiliar. The career program denominated natural receive more than one subject related to finance, enlightened at least financial math and unfamiliar doesn't receive subjects in finance. The "natural" group is from three programs: economics, audit and business administration; the "enlightened" participate with eight programs and "unfamiliar" with twenty-two programs.

The final results were 185 "naturals,"104 "enlightened" and 189 "unfamiliar" participants or a sample of 478 university students evaluated. This is the result of stratified random sampling(12) of 9,646 ESPOL Polytechnic University students.

\section{TABLE 1}

Data collected Schedule.

\begin{tabular}{|c|c|c|c|c|c|c|c|}
\hline \# & Subject & Day & Room & Hour & Professor & $\begin{array}{l}\text { \# } \\
\text { students }\end{array}$ & Program \\
\hline 1 & Communication one & Jan 31th 2018 & ICM-BA21 & $15: 30$ & Claudia Marquez & 37 & Mix \\
\hline 2 & Specific Design Foods & Feb 1st 2018 & 24E-199 & 09:30 & Grace Vasquez & 14 & Foods engineering \\
\hline 3 & Calculation of Various Variables & Feb 1st 2018 & ICM-BA26 & $11: 30$ & María Nela & 48 & Mix \\
\hline 4 & Design Thinking & Feb 1st 2018 & IB-25 & $12: 10$ & Adriana Santos & 21 & Mix \\
\hline 5 & Science and materials engineering & Feb 1st 2018 & Materials Lab. & $14: 50$ & Ana Rivas & 18 & Materials engineering \\
\hline 6 & Organic Chemistry $2 \mathrm{P} \# 2$ & Feb 1st 2018 & $27 \mathrm{~A}-105$ & $15: 30$ & Haci Baykara & 20 & Chemical engineering \\
\hline 7 & Macroeconomics 2 & Feb 1st 2018 & IB-17 & $16: 00$ & Juan C.Campuzano & 28 & Economics \\
\hline 8 & Capital Markets & Feb 1st 2018 & Lab. Delta & $17: 15$ & Mariela Méndez & 35 & International Bussiness \\
\hline 9 & Marketing Research & Feb 8th 2018 & B-109 & $07: 30$ & Heidy Pazmino & 53 & Graphic design \\
\hline 10 & Socio-emotional Education & Feb 9th 2018 & IC-21 & $08: 30$ & Aglae Febres Cordero & 72 & Mix \\
\hline 11 & Socio-emotional Education & Feb 9th 2019 & IC-25 & $08: 30$ & Gloria Febres Cordero & 50 & Mix \\
\hline 12 & Marketing Research & Feb 9th 2018 & IC-15 & 11:00 & Heidy Pazmino & 30 & International Bussiness (R.I.P.) \\
\hline 13 & Technical visit & Feb 16th 2018 & $\begin{array}{l}\text { Bus } \\
\text { Professor }\end{array}$ & 08:00 & Isabel Alcivar & 17 & Industrial engineering \\
\hline 14 & Operational research & Feb 16th 2018 & FIMCP & 09:30 & Jenny Gutierrez & 7 & Mix \\
\hline 15 & Optimization 2 & Feb 16th 2018 & IB-24 & $12: 00$ & David Desantis & 28 & Mix \\
\hline
\end{tabular}

The data collection process was in a pen and paper version with fifteen groups of volunteer students acceptant to be part of the program research (see table 1).

Multivariate Analysis (MVA) was applied to analyze the data. The relationship between demographic and socioeconomic with FL scores was evaluated with descriptive statistics.

The FL score like a first approach calculation is analyzed as the average of the total addition points obtained in FA, FB and FK section. It seems like 90 points of FA, 75 points of FB and 
13 points of FK. The maximum value is transformed as a percentage of $100 \%$, and then a simple average, the FL score could fluctuate between 0 to $100 \%$. Where $100 \%$ is a perfect score. (see table 2)

This process to obtain a score from FA, FB, FK and then for FL, is proposed like an FL valuation index. This process will be applied to obtain a score for any further people taking this survey.

A test of three questions was developed to proof the relationship between financial literacy and specific socioeconomic and demographic variables with the Kruskal-Walis Test and the Wilcoxon test $(13,14)$. The next three questions:

Who is more financially literate? D14 the naturals more than others? D16 the students with a higher academic score? and FPT1 the students who chose a house and pension plan as a priority?

\section{RESULTS}

The quantity of missing data is reasonable and in the accepted limits (15). 94 of 478 surveys are uncompleted in at least 1 answer, and 40 of 61 questions proposed were ignored at least once, as well.

Most of the participants are single, living with their parents in urban areas, from private high school, unknowing their academic scores at the university as a result of a youth sample. 50\% of the participants are registered around the first four semesters of every program distributed in 33 programs analyzed.

The particular question included in this survey and named as financial place and time section, show the preference, "house" before "car" and "trip of your dream" before "furniture." The retirement account is the last option chosen for them. This is an important issue to remark in second research focused on how to increase their financial literacy level. The last option, retirement account, and their focus prevision are described in the study of Lin et al. (16).

We have compared the general score obtained by section with 90 points of FA, 65 points of FB and 13 points of FK. Financial Attitude is, in this case, the section better evaluated with a remarked result $(55 \%$ of the sample obtained more than $80 \%$ of the score) followed by financial behavior where the data is more distributed to the middle $(22 \%$ of the sample obtained more than $80 \%$ of the score). FK has the lowest performance compared with FA and FB. (see figure 1)

\section{TABLE 2}

\# Students per Class of FA, FB, FK.

\begin{tabular}{ccccc}
\hline Class \% & FA (90 points) & FB (65 points) & FK (13 points) & FL. SA \\
\hline $0-20$ & 0 & 7 & 55 & 1 \\
$20-40$ & 3 & 27 & 133 & 14 \\
$40-60$ & 11 & 119 & 119 & 133 \\
$60-80$ & 200 & 218 & 143 & 295 \\
$80-100$ & 264 & 107 & 28 & 35 \\
\hline
\end{tabular}


This result could be affected for the kind of evaluation tool applied to compare to the study of Potrich et al. (7) where they used a broader age's range of the population. Our study focuses on a population with an age range of 18-23 university students. This result is not corroborated (17), but financial behavior is a genuine and determining element for financial literacy.

Financial knowledge occupies the third place where only $5.8 \%$ of the sample obtained a score of more than $80 \%$.

The "natural" group is better in financial literacy, but "unfamiliar" occupies the second place in this analysis followed by "enlightened." The reason could be the kind of sample analyzed (youth) and the numeracy involved in the formation of chemical and computer science engineering (18).

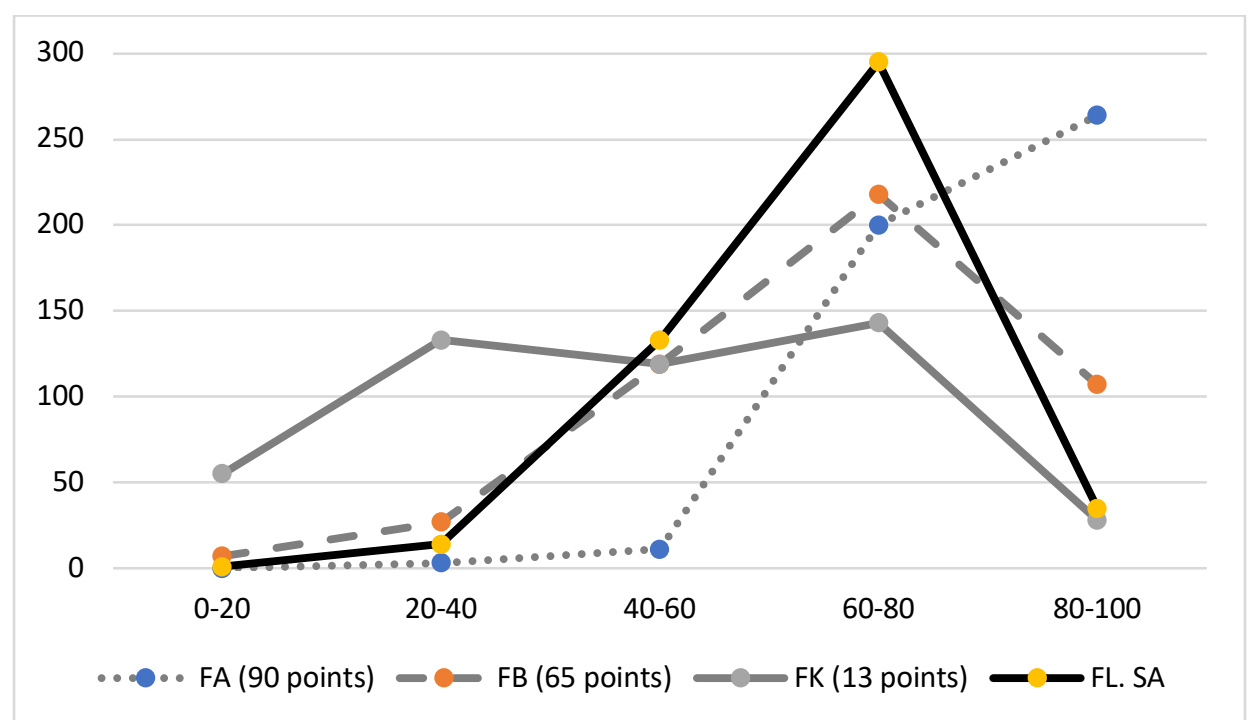

Figure 1: General results from financial attitude, behavior, knowledge, and financial literacy.

People with Higher education levels have higher financial literacy levels. The number of courses related to the financial field attended at an undergraduate education is related to the financial literacy level and those are corroborated in this study. Those with lower education are less likely to answer the questions correctly and more prone to say they do not know the answer (19).

Inconsistency between some approved subjects and the level of the program is found. $25 \%$ of the students analyzed are preparing for their graduation, and they obtained better scores of financial literacies and their components, behavior, attitude, and knowledge, but in this research, financial attitude is the dimension with better perfomance among the people evaluated.

Central components of financial literacy are numeracy and the emotional attitude towards numbers (i.e. mathematics anxiety). As a consequence of that, having plans for retirement is also associated with financial literacy. Youth were less likely to think much about retirement planning. (21), (22), (19). 59\% of the students chose a "House" as priority, following with 18\% a "car", 9\% "travel", 4\% "retirement account" and 3.5\% for "furniture". The rest of the students have not responded to this question. The students who chose retirement account as priority obtained $71 \%$ of financial literacy score, and this is quite higher than $65 \%$ from House choosers. 
Who is more financially literate?

TABLE 3

Relationship between Demographic variables and FL score.

\begin{tabular}{|c|c|c|c|c|}
\hline $\begin{array}{l}\text { Survey's } \\
\text { Code }\end{array}$ & Variable & $\begin{array}{l}\text { Question: } \\
\text { Who is more financially } \\
\text { literate? }\end{array}$ & $\begin{array}{l}\text { Kruskal Wallis } \\
\text { Test (P- } \\
\text { value): }\end{array}$ & $\begin{array}{l}\text { Wilcoxon Test } \\
\text { (P-value): }\end{array}$ \\
\hline D14 & My Program study & $\begin{array}{l}\text { The naturals more than } \\
\text { others? }\end{array}$ & & 0,00 \\
\hline D16 & $\begin{array}{l}\text { My Score during } \\
\text { program study }\end{array}$ & $\begin{array}{l}\text { my The students with the higher } \\
\text { academic score? }\end{array}$ & 0,022 & \\
\hline FPT-1 & $\begin{array}{l}\text { Choosing betwe } \\
\text { House, car } \\
\text { pension plan }\end{array}$ & $\begin{array}{l}\text { een The students who chose a } \\
\text { orhouse and the pension plan } \\
\text { as a priority? }\end{array}$ & 0,130 & \\
\hline
\end{tabular}

According to the Kruskal-Walis Test and the Wilcoxon test $(13,14)$ none relationship exists between FL score and academic score and type of KFD decision maker (see table 3). The hypothesis is accepted only with the program study variable. The FL score depends on the program study. It seems like the natural group is expected to have the highest FL score as a result of their specialization.

\section{CONCLUSIONS}

The type of program affects the Financial Literacy score. People with FL score more than $90 \%$ is from the natural group, the specialist.

The financial Knowledge is affected by numeracy more than the specialization kind because the unfamiliar group obtained a higher FL score beside the natural group.

The results reveal numeracy as the principal reason to understand how people from the group "unfamiliar" reached better performance than "enlightened" and how the naturals are not the most financially conscious.

This finding is an important contribution trying to measure the efficacy of financial education into career programs at the universities. According to Skagerlund et al. we would not only raise the level of numeracy in the general population but also raise the level of financial literacy in society as well. This potential dual-effect of increasing numeracy in the population is worthy of further exploration (21).

\section{REFERENCES}

1. Roy D, Zeckhauser R. The anatomy of ignorance Diagnoses from literature. 2006;6174.

2. $\quad$ SBS S de B del E. CAPÍTULO IV.- De los Programas de Educación Financiera por parte de las Entidades Controladas por la Superintendencia de Bancos y Seguros. 2013;216-39.

3. Mudzingiri C, Muteba Mwamba JW, Keyser JN. Financial behavior, confidence, risk preferences and financial literacy of university students. Cogent Econ Financ [Internet]. 2018;6(1):1-25. Available from: https://www.cogentoa.com/article/10.1080/23322039.2018.1512366

4. Konicz AK, Mulvey JM. Optimal savings management for individuals with defined 
contribution pension plans. Eur J Oper Res [Internet]. 2015 May [cited 2018 Jan 3];243(1):233-47. Available

from:

http://linkinghub.elsevier.com/retrieve/pii/S0377221714009205

5. Berri A. A cross-country comparison of household car ownership. IATSS Res [Internet]. 2009 [cited 2018 Jan 2];33(2):21-38. Available from: http://linkinghub.elsevier.com/retrieve/pii/S0386111214602429

6. Martin M. A Literature Review on the Effectiveness of Financial Education. Most. 2007;1-26.

7. Potrich ACG, Vieira KM, Kirch G. How well do women do when it comes to financial literacy? Proposition of an indicator and analysis of gender differences. J Behav Exp Financ [Internet]. 2017; Available from: https://doi.org/10.1016/j.jbef.2017.12.005

8. CFL and RI C for FL and RI. Financial Knowledge and Behaviour Survey 2013. Colmar Brunton, Soc Res Agency. 2013;6-10.

9. Kiliyanni AL, Sivaraman S. International Review of Economics Education The perception-reality gap in fi nancial literacy: Evidence from the most literate state in India. Biochem Pharmacol [Internet]. 2016;23:47-64. Available from: http://dx.doi.org/10.1016/j.iree.2016.07.001

10. van Rooij M, Lusardi A, Alessie R. Financial literacy and stock market participation. J financ econ. 2011;101(2):449-72.

11. Capability F, Protection C, Report S, Inclusion F, Protection C, Line S. Paving the road to better Financial Decision-Making in. 2013;(August).

12. Marshall MN. Sampling for qualitative research. Fam Pract [Internet]. 1996;13(6):5226. Available from: http://dx.doi.org/10.1093/fampra/13.6.522

13. Kruskal WH, Wallis WA. USE OF RANKS IN ONE-CRITERION VARIANCE ANALYSIS. J Am Stat Assoc. 1955;47(260):584-618.

14. Wilcoxon F. Individual Comparisons by Ranking Methods. Int Biometric Soc. 1945;1(6):80-3.

15. Blackwell M, Honaker J, King G. A Unified Approach to Measurement Error and Missing Data: Overview and Applications. Sociol Methods Res. 2017;46(3):303-41.

16. Lin C, Hsiao YJ, Yeh CY. Financial literacy, financial advisors, and information sources on demand for life insurance. Pacific Basin Financ $J$ [Internet]. 2017;43(April):218-37. Available from: http://dx.doi.org/10.1016/j.pacfin.2017.04.002

17. Klapper L, Lusardi A, Panos GA. Financial literacy and its consequences: Evidence from Russia during the financial crisis. J Bank Financ [Internet]. 2013 Oct;37(10):3904-23. Available

from: http://linkinghub.elsevier.com/retrieve/pii/S0378426613002847

18. Huston SJ. Measuring Financial Literacy. J Consum Aff [Internet]. 2010 Jun;44(2):296-316. Available from: http://doi.wiley.com/10.1111/j.17456606.2010.01170.x

19. Boisclair L\& M. Journal of Pension Economics and Finance - Financial literacy and retirement planning in chile - Cambridge Journals Online. 2017. p. Volume 16, Special Issue 3 (Financial Knowledge an.

20. Longobardi S, Pagliuca MM, Regoli A. Can problem-solving attitudes explain the gender gap in financial literacy? Evidence from Italian students' data. Qual Quant [Internet]. 2018 Jul 2 [cited 2018 Oct 19];52(4):1677-705. Available from: http://link.springer.com/10.1007/s11135-017-0545-0

21. Skagerlund K, Lind T, Strömbäck C, Tinghög G, Västfjäll D. Financial literacy and the role of numeracy-How individuals' attitude and affinity with numbers influence financial literacy. J Behav Exp Econ [Internet]. 2018 Jun;74:18-25. Available from: https://linkinghub.elsevier.com/retrieve/pii/S2214804318301241 
22. Garg N, Singh S. International Journal of Social Economics. Int J Soc Econ Manag Res Rev [Internet]. 2016;43(3):356-76. Available from: https://doi.org/10.1108/IJSE-112016-0303 